\title{
THE EFFECT OF USING PEER TUTORIAL METHOD IN TEACHING SPEAKING OF SMP NEGERI 2 ANGKOLA TIMUR
}

\author{
Oleh: \\ ABDUL RAHMAN SIAGIAN \\ Program Studi Pendidikan Bahasa Inggris UMTS Padangsidimpuan \\ Email: Abdul.rahman@um-tapsel.ac.id
}

\begin{abstract}
The researcher conducted this research at the Grade VIII Students of SMP Negeri 2Angkola Timur. The aims of this research was to find out is there a significant effect of using peer tutorial method in speaking ability of SMP Negeri 2 Angkola Timur. In achieving the purposes of this research, the writer carried out in quantitative approach by applying experimental method. The population of this research was 80 students and the writer uses total sampling technique to get of students. The speaking ability was applied as the instrument of this research; the writer used " $t$ " test formula.Based on the data that has been analyzed, it can be found that (1) the students' achievement of speaking was "very good" (80,5), (2) there is a significant effect of using peer tutorial method in speaking ability of SMP Negeri 2 Angkola Timur.
\end{abstract}

\section{Key Words: Peer Tutorial Method, Teaching Speaking}

\section{INTRODUCTION}

English is a very important language that is used by many people in various countries. It is very useful for us and our future. English is the first language in many aspects in life, such as in everyday life, business, information technology, education especially senior high school and university education, and many other aspects.

Speaking is truly basic skill in language learning because it is frequently used in daily life to carry out conversation with others and often measured as the success of learning foreign language. Thus, many students regard speaking as the most important skill they can acquire and assess for their progress in accomplishing spoken communication. Through speaking the speaker convey his/her idea or knowledge in verbal form.

Speaking has important role because it is as a tool of communication in learning English. Thus, the students should prepare themselves to get more knowledge related to English in particularly and others in general. In junior high school curriculum, speaking ability has aim to inform or to communicate information. Depdiknas (2006:2) stated that purpose of teaching English in junior high school, the students were able to communicate in 
informational level namely transactional and intransactional. It meant that the students should able to develop their communicate competency in orally or written level.

Looking at the above purpose, there were many efforts to hold them, such as: applying the suitable method, prepare the effective teaching, giving motivation, facilities, and so forth. Another way that can be applied to get the aim is prepare the material which support teaching English, such as: motivating the students, arising students' self confidence, pronunciation, phonology mastery, gesture, and so on.

In the field, the teaching speaking of students is still far from the expectation. This is known from first observation to the grade VIII students of SMP Negeri 2Angkola Timur. As the result, the writer got the fact was supported with average score of the students. Majority (more than 60\%) of the students had 70 in students' list of value(Daftar Kumpulan Nilai; $D K N)$ for English subject, while their minimal target in minimal target score(Kriteria Ketuntasan Minimal; KKM) was 70. It meant that the students could not get their target in English subject. Thus, it could be said that the students still had problem in teaching English, especially in speaking ability.

By seeing the problem above, the researcher assumed that there were many factors that influenced the successfulness of the students in speaking ability. The factors were: motivation, interest, part of speech, pronunciation, phonology mastery, and gesture, personality of the teacher, environment, and teaching method.

Considering to the above condition, teaching method had important role in increasing the speaking ability of students. It was because teaching method provided specific steps which can be used toward teaching and learning process, especially to teaching the speaking ability.

Actually, there are many teaching methods which can be used in teaching speaking ability, such as: peer tutorial method, sociodrama method, demonstration method, inquiry method, discussion method, cooperative method, and so forth. Thus, for this case, the writer thinks that the suitable methods which can be used to solve the students' condition above are peer tutorial method.

Peer tutorial method is a student will be asked to be a tutor and mentor for the other friends, whereby fellow teachers, as each other's colleagues, conduct cycles of clinical supervision with each other with the overall coordination of a facilitator/leader. A smarter student has a responsibility for his or her friend in the group.

\section{The Nature of Speaking Ability}

Speaking is one of
important aspect communication. Speaking is an interactive process of constructing meaning that involves producing and receiving and processing information. It also can be said as transferring the information from the speaker to the hearer.

According Nation and Newton (2009: 1) speaking is 
elements of learning language which focused to learning through meaning-focused output; where the learner's attention is on conveying ideas and messages to another person. It means that speaking is an element of learning language which is focused to convey ideas and messages to others orally. It also indicates that speaking should be focused on the output or product of the information.

Brown (2004: 140) says that defines speaking as a productive skill that can be directly and empirically observed; those observations are invariably colored by the accuracy and effectiveness of a test- taker's listening skill, which necessarily compromises the reliability and validity of an oral production test.

From those statements

above, the researcher can conclude that speaking is an activity involving 2 or more people in which the participants are both the listeners and the speakers having to act what they listen and make their contribution at high speed. According to Ochs and Klinker which is quoted byJuli(2012: 166) say that speaking is also the mixture to inform and entertain and persuade.

WhileSanggamSiahaan says, "Speaking is the spoken productive language skill."
Similarly, Louma (2009: 15) said that in speaking, the word order does not seem 'broken' in any sense, however, since the aim is to emphasize the topic". It means that in speaking the sense of the topic is the important. In this case, in speaking process the speaker should pay attention to the sense of information is being conveyed. It means that the topic should be kept.

Furthermore, Barras (2009: 16) said that speaking is process to convey more information and make your point more forcefully if you make eye contact with each listener than if you rely on words alone. As a result of such non-verbal communication, those involved in a conversation or discussion understand more than is actually said - whereas listeners to a recorded conversation can learn only from what was said. Automatically the speaking is conveying more information and makes your point more forcefully to the listener. Therefore, the listener can learn the ideas through what is said by the speaker.

Furthermore, Hedge (2008: 261) said that speaking as communicative approach have developed, teachers have been concerned to ensure that students not only practice speaking in a controlled way in order to produce feature of pronunciation, vocabulary, and structure accurately, but also practice using these features 
more freely in purposeful communication. It means that to get communicative approach in speaking, teachers should teach the students the using of pronunciation, vocabulary, and structure accurately. Therefore, the indicators which are used in speaking ability for this research are: a) grammar, b) pronunciation, and c) vocabulary.

Based on the quotation above, the reseacher concludes that vocabulary is medium to manage and organize conversation. It is also used to improve language aspects. Therefore, vocabulary is one of successful aspect in language learning because vocabulary is builtby some words, and it is known that words is basis for speaking.

\section{The Nature of Peer Tutorial Method}

Teaching is defined the way taht is used by the teacher or instructor in doping his/her functions as a tool for learning achievement. Teaching method contains certain steps that are arranged procedurally.Syaiful Sagala (2003:201) says that all teaching method that are used must be related to the goals of teaching learning process, hence, the teacher should understand the function, steps in a teaching method.

Tutorial method is the terminology of teaching and learning process by giving counseling to the student.
Tutorial can be given by the teacher to their student (peer tutorial) or other people as a guest (guest tutorial), or other students whose class is higher (cross-age tutorial).

This teaching method was invented by Socrates. It sprang from the character of the Greek people who loved asking question and arguing them out. In the process of answering questions on the part of the students, was made to realize that knowledge and truth were in the students' own power to find. If they care to search long enough and hard enough. It is in the combination of these two assumptions, namely: the critical method and positive purposes of self-assertion, where the essence of tutorial method lies.

According to Duch et al (2001:42), "Peer or near-peer tutors can be utilized to extend the ability to check the functioning of individual groups and assure that the group discussions probe for deeper levels of understanding". The aim of the method is the situation how to increase the level of knowledge and understanding of the leader to transfer his/ her ability about the learning material. 


Similarly, Glickman
(2002:14) said that peer
coaching is a structure
whereby fellow teachers, as
each other's colleagues,
conduct cycles of clinical
supervision with each other
with the overall coordination
of a facilitator/leader. It means
that peer learning is a process
that involves two or more
individuals who integrate
verbally and facedly about
certain aims and goals through
informational sharing, self-
maintenance or problem
solving by their own, a smarter
student as a leader that has a
responsibility to other friend in
the group, so a smarter
studenttrying toteachhis/her
friendtohave an insight, a
similarunderstanding.
addition, the aim of this
method is to make a process
transferring understanding
about the learning material
more easier, because a smarter
student has a good
responsibility to her/ his friend.
Suparman (1997:205) said that
learnt through tutorial is more
increase of material mastery,
democratic and give
advantages to both tutor and
tutee. The main pointed of the
quotation are democratic and
give advantages to both tutor
and tutee. It means that tutorial
methods make the student

more democratic, by giving same opportunities to other students as a tutor in the teaching and learning process. In another word, Oemar Hamalik (2001:73) said that tutorial is learning by giving counseling formed, helping, guiding, and motivating in order the students study efficiently and effectively. It meant that tutorial method is a form of counseling and learning helping that is very potential to improve the students' achievement. Therefore, tutor gets positive effect to the students, to make tutorial method well, a teacher/tutor must be tried in order to give him skill for giving counseling and learning helping.

Based on the explanation previously, the researcher concludes that peer tutorial method is a teaching method in which one student is chosen by the teacher to be a tutee. It is of course, in choosing the teacher takes some consideration. Peer tutorial as a teaching method is highly favorable in assuring the realization of widely held objectives of a collage general education, namely: selfunderstanding, critical and analytical thinking, creative self-expression, intelligent application of knowledge to 
life-situation, and oral and written facility.

\section{METHODOLOGY RESEARCH}

OF

This research was conducted at the SMP Negeri 2 Angkola Timur. The reasons why the researcher took this school as location of the research because this school active in teaching and learning process. Thus, the data that was needed in this research can be found in the school. Next, this research will be run about three months. The writer worked to collect data, analyzed, and make a research report.

In conducting this research, experimental research design is used to look whether there is an effect of the treatment to certain ability in teaching and learning process. Then, one class design experimental class can be done if it just have one treatment. Therefore, $0_{1}$ is used to show the teaching and learning process without the treatment and the other one it tends to the teaching and learning by using the treatment. In this case, expository method is used as certain treatment and it will be applied in $0_{2}$. Therefore, to know how the treatment gives an effect, it should be compared between result on $0_{1}$ and $0_{2}$. In other words, comparing between pre-test and post-test show how the treatment gives its effect on experimental research.

Furthermore, it can be said that ppopulation has been planned to be a target of generalization or conclusion. Hence, the researcher determines to takes the of SMP Negeri 2Angkola Timur with 80 students. To have the sample, the researcher usedtotal sampling. In getting data of the research, the researcher uses observationa $\mathrm{dn}$ test. Then the researcher takes descriptive and statistic analysis by t-Test to analyze the data.

\section{RESULT OF THE RESEARCH}

After analysing the data, the researcher get three results. In this case, the writer shows them into these elaboration.

\section{Result of Teaching Speaking in Pretest}

The lowest distribution score of students after conducting the peer tutorial method is 55 and the highest score is 85. It is concluded in order to know the description of the data, from the calculation. The writer served them on the following table:

Table 1

The Data of Speaking Ability in Posttest.

\begin{tabular}{|l|l|l|}
\hline No & Students' Name & Score \\
\hline 1. & Abdul Wahid & 70 \\
\hline 2. & Ahmad Syafii & 70 \\
\hline
\end{tabular}




\begin{tabular}{|l|l|l|}
\hline 3. & Amirul Saddad & 65 \\
\hline 4. & Bella Hassa & 80 \\
\hline 5. & Basirun & 60 \\
\hline 6. & Desi & 70 \\
\hline 7. & Edi iskandar & 65 \\
\hline 8. & Endang Sari & 70 \\
\hline 9. & Fahrian Rifandi & 80 \\
\hline 10. & Hidayat & 65 \\
\hline 11. & Irfan Maseh & 65 \\
\hline 12. & Khodijah & 75 \\
& matondang & \\
\hline 13. & $\begin{array}{l}\text { Muhammad } \\
\text { Rahim }\end{array}$ & 75 \\
\hline 14. & Nur Ainun & 70 \\
\hline 15. & Nilada Maya Sari & 65 \\
\hline 16. & Nita Aprilia & 80 \\
\hline 17. & Parlugutan & 65 \\
\hline 18. & Pauzan Ashar & 60 \\
\hline 19. & Rahmadani & 65 \\
\hline 20. & Rahma & 75 \\
\hline 21. & Rahmi & 75 \\
\hline 22. & Rohimah & 70 \\
\hline 23. & Rafi Aulia Rozi & 65 \\
\hline 24. & Resi adelia & 75 \\
\hline 25. & Rahmad rifaii & 70 \\
\hline 26. & Rini Kartika & 60 \\
\hline 27. & Lesma Yunita & 85 \\
\hline 28. & Sulhardi & 55 \\
\hline 29 & Siti Aisyah & 85 \\
\hline 30. & Madung Yusuf & 70 \\
\hline 31. & Aprida & 55 \\
\hline 32. & Tasya Syabila & 85 \\
\hline 33 & Ulil Amri & 70 \\
\hline 34 & Ilham Rozani & 70 \\
\hline 35 & Indra Kurniawan & 80 \\
\hline 36 & $\begin{array}{l}\text { Haddad Fadli } \\
\text { lubis }\end{array}$ & 60 \\
\hline 37 & Masdewi & 70 \\
\hline 38 & Boy Irwan & 55 \\
\hline 39 & Tarmizi & 70 \\
\hline 40 & Syawaldi & 60 \\
\hline Total & & \\
\hline & & \\
\hline & & \\
\hline 3.75 \\
\hline 3.
\end{tabular}

From the table above, It was found that.

The sum of the students' consisted of 40 students was 2775 . Then, it was found that the higest score was 85 and the lowest was 55 . Further, It is found that the average or mean is 69.3 the median is 75 and the mode is 70. It is categorized "Enough". To make it clear, the description of mean, median and modus can be seen as following table

a. Mean

Mean was very important to get the true score. First, the writer must calculate the sum of the score and then the score can be divided to the number of the students. Order to be clear, the writer presented them in the formula as follows:

$$
\mathrm{M}_{\mathrm{y}}=\frac{\sum X}{N}
$$

Where:

$$
\begin{aligned}
& M=\text { students' mean score } \\
& \begin{array}{l}
\sum \mathrm{X}=\text { sum of the students' score } \\
\mathrm{N}=\text { the number of } \\
\text { students } \\
=\frac{2775}{40} \\
=69.3
\end{array}
\end{aligned}
$$

Referred to the calculation above, the means score was 69.3. thus, 
it was known that almost of the students to produce good pronunciation, grammar and vocabulary. But some of them are still weak in pronunciation, grammar and vocabulary. Furthermore, it needed to train in order to get the good teaching speaking.

b. Median

Median is the center of value which was taken from the rows data. The data must have arrangement from lowest to the highest score. As showed in the previous table, it was teaching speaking in pre-test. The data such as: $55-55-55-60-60-$ $60-60-60-65-65-65-65$ $-65-65-65-65-70-70-$ $70-70-70-70-70-70-70$ $-70-70-7075-75-75-75$ $-75-80-80-80-80-85$. $85-85$.

Median of the data was 80 - 80. Median took from divided the all data into two part. And then, took the score in the middle. In order to be clear and brief the writer served it on the following:

$$
\begin{aligned}
\text { Mey } & =\frac{70+70}{2} \\
& =70
\end{aligned}
$$

From the calculation the median was 70 .

c. Mode
Mode is the value that often to be showed. The data must be rows to get the true mode. The data like: $55-55-$ $55-60-60-60-60-60-65$ $-65-65-65-65-65-65-$ $65-70-70-70-70-70-70$ $-70-70-70-70-70-7075$ $-75-75-75-75-80-80-$ $80-80-85-85-85$.. From the data rows, the researcher could get the mode was 70 .

\section{Result of Teaching Speaking in Post-test}

After collecting the data, it was found that the lowest score of the students before conducting the peer tutorial method the lowest score is 65 and the highest score is 95. It is concluded in order to know the description of the data, from the calculation.

Table 2

The Data of Speaking Ability in Pretest

\begin{tabular}{|l|l|l|}
\hline No & Students' Name & Score \\
\hline 1. & Abdul Wahid & 65 \\
\hline 2. & Ahmad Syafii & 85 \\
\hline 3. & Amirul Saddad & 70 \\
\hline 4. & Bella Hassa & 75 \\
\hline 5. & Basirun & 80 \\
\hline 6. & Desi & 75 \\
\hline 7. & Edi iskandar & 90 \\
\hline 8. & Endang Sari & 80 \\
\hline 9. & Fahrian Rifandi & 80 \\
\hline
\end{tabular}




\begin{tabular}{|c|c|c|}
\hline 10. & Hidayat & 65 \\
\hline 11. & Irfan Maseh & 85 \\
\hline 12. & $\begin{array}{l}\text { Khodijah } \\
\text { matondang }\end{array}$ & 75 \\
\hline 13. & $\begin{array}{l}\text { Muhammad } \\
\text { Rahim }\end{array}$ & 80 \\
\hline 14. & Nur Ainun & 85 \\
\hline 15. & Nilada Maya Sari & 70 \\
\hline 16. & Nita Aprilia & 90 \\
\hline 17. & Parlugutan & 85 \\
\hline 18. & Pauzan Ashar & 75 \\
\hline 19. & Rahmadani & 90 \\
\hline 20. & Rahma & 80 \\
\hline 21. & Rahmi & 80 \\
\hline 22. & Rohimah & 90 \\
\hline 23. & Rafi Aulia Rozi & 65 \\
\hline 24. & Resi adelia & 80 \\
\hline 25. & Rahmad rifaii & 80 \\
\hline 26. & Rini Kartika & 75 \\
\hline 27. & Lesma Yunita & 80 \\
\hline 28. & Sulhardi & 90 \\
\hline 29 & Siti Aisyah & 70 \\
\hline 30. & Madung Yusuf & 80 \\
\hline 31. & Aprida & 85 \\
\hline 32. & Tasya Syabila & 95 \\
\hline 33 & Ulil Amri & 80 \\
\hline 34 & Ilham Rozani & 70 \\
\hline 35 & Indra Kurniawan & 95 \\
\hline 36 & $\begin{array}{l}\text { Haddad } \\
\text { lubis }\end{array}$ & 85 \\
\hline 37 & Masdewi & 80 \\
\hline 38 & Boy Irwan & 80 \\
\hline 39 & Tarmizi & 95 \\
\hline 40 & Syawaldi & 85 \\
\hline \multicolumn{2}{|c|}{ Total } & 3220 \\
\hline
\end{tabular}

From

That the sum of the students' consisted of 40 students was 3220 . Then, it was found that the higest score was 95 and the lowest was 65 .Thus, average or mean is 80.5 , the median is 80 and the mode is 80 . The categorized is "very good".
To make it clear, the description of mean, median and modus can be seen as following table:

\section{a. Mean}

Mean is the numeral that represent to all the data in average. The mean was very important because to know the average of the students' value. The calculation can be seen on the following:

$\mathrm{M}=\frac{\sum X}{N}$

Where:

$$
\begin{aligned}
& \mathrm{M}=\text { students' mean score } \\
& \Sigma \mathrm{X}=\text { sum of the students' score } \\
& \mathrm{N}=\text { the number of students }
\end{aligned}
$$

$$
\begin{aligned}
& M=\frac{3220}{40} \\
& =80.5
\end{aligned}
$$

Based on the calculation above, the writer had found that the mean was 80.5. Furthermore, it was almost of all the students got score in exceed of the average. Therefore, they still difficult in pronounciation. It meant that they needed to increase their pronunciation.

\section{b. Median}

Median is the center of value which was taken from the rows data. The data must have arrangement from lowest to the highest score. As showed in the previous table, it was teaching speaking in pre-test. The data such as: $65-65-65-70-70-70-70$ 
$-75-75-75-75-75-80-80$

$-80-80-80-80-80-80-80$

$-80-80-80-80-85-85-85$

$-85-85-85-85-90-90-90$

$-90-95-95-95$.

Median of the data was $80-$ 80. Median took from devided the all data into two part. And then, took the score in the midle. In order to be clear and brief the writer served it on the following:

$$
\begin{aligned}
\operatorname{Me}_{\mathrm{x}} & =\frac{80+80}{2} \\
& =80
\end{aligned}
$$

So the median of the data was 80

\section{c. Mode}

Mode is the value that often to be showed. The data must be rows to get the true mode. The data like: : $65-65-65-70-70-70-$ $70-75-75-75-75-75-80-$ $80-80-80-80-80-80-80-$ $80-80-80-80-80-85-85-$ $85-85-85-85-85-90-90-$ $90-90-95-95-95$. From the data rows, the writer could get the mode was 80 .

By paying attention to the calculation above, it means that in teaching speaking before using peer tutorial has satisfied based on the categorize value. The ability of the students in speaking ability before using peer tutorial is called the expectation standard score. It shows in the score of each indicators..
The following table shows the data distribution of teaching speaking ability before using peer tutorial method:

Range $=$ Highest score - Lowest score

$$
\begin{aligned}
& =95-65 \\
& =30
\end{aligned}
$$

Number of class $(\mathrm{k})=1+(3.3)($

$$
\begin{aligned}
& \left.\log _{N}\right) \\
& =1+(3.3)\left(\log _{40}\right) \\
& =1+(3.3)(1.60) \\
& =1+5.28 \\
& =6.28
\end{aligned}
$$

$$
\begin{aligned}
\operatorname{Interval}(\mathrm{i}) & =\frac{R}{K} \\
& =\frac{30}{6.28}=4.7=5
\end{aligned}
$$

Table 3

The Distribution Frequency in Speaking Ability before Using

Peer Tutorial Method

\begin{tabular}{|l|l|l|l|l|}
\hline No & $\begin{array}{l}\text { Interv } \\
\text { al }\end{array}$ & $\begin{array}{l}\text { Freq } \\
\text { uenc } \\
\text { y }\end{array}$ & $\begin{array}{l}\text { Freque } \\
\text { ncy } \\
\text { Cumul } \\
\text { ative }\end{array}$ & $\begin{array}{l}\text { Perc } \\
\text { enta } \\
\text { ge }\end{array}$ \\
\hline 1 & $\begin{array}{l}65- \\
69\end{array}$ & 3 & 3 & $\begin{array}{l}7.5 \\
\%\end{array}$ \\
\hline 2 & $\begin{array}{l}70- \\
74\end{array}$ & 4 & 7 & $\begin{array}{l}10 \\
\%\end{array}$ \\
\hline 3 & $\begin{array}{l}75- \\
79\end{array}$ & 5 & 12 & $\begin{array}{l}12.5 \\
\%\end{array}$ \\
\hline 4 & $\begin{array}{l}80- \\
84\end{array}$ & 13 & 25 & $\begin{array}{l}32.5 \\
\%\end{array}$ \\
\hline
\end{tabular}




\begin{tabular}{|l|l|l|l|l|}
\hline 5 & $\begin{array}{l}85- \\
89\end{array}$ & 7 & 32 & $\begin{array}{l}7.5 \\
\%\end{array}$ \\
\hline 6 & $\begin{array}{l}90- \\
94\end{array}$ & 5 & 37 & $\begin{array}{l}12.5 \\
\%\end{array}$ \\
\hline 7 & $\begin{array}{l}95- \\
100\end{array}$ & 3 & 40 & $\begin{array}{l}7.5 \\
\%\end{array}$ \\
\hline $\begin{array}{c}\text { Tota } \\
1\end{array}$ & 40 & & \multicolumn{2}{|c|}{$100 \%$} \\
\hline
\end{tabular}

Based on the frequency distribution above, the writer has found that the students who get the score $95-100$, they are 3 students or $7.5 \%$, while the students who get the score $85-89$, they are 7 students or $17.5 \%$, the score $80-84$ are 13 students or $32.5 \%$, the score $75-79$ are 5 students or $12.5 \%$, the score $70-$ 74 are 4 students or $10 \%$, and the last score $65-69$ are 3 students or $7.5 \%$.

By paying attention to the calculation above, the mean, median and mode of using discussion method in teaching speaking ability. The students'speaking ability by using peer tutorial method is still almost complete.

The following table showed the data distribution for the students in speaking ability by using peer tutorial method.

$$
\begin{aligned}
& \begin{aligned}
\text { Range } & =\text { Highest score }- \text { Lowest } \\
\text { score } & \\
& =85-55 \\
& =30
\end{aligned}
\end{aligned}
$$

$$
\begin{aligned}
& \text { Number of class }(\mathrm{k}) \\
& \begin{array}{ll}
\left.\log _{N}\right) & 1+(3.3)( \\
& =1+(3.3)( \\
& \left.\log _{40}\right) \\
& =1+(3.3) \\
& (1.60) \\
& =1+5.28 \\
& =6.28 \\
\text { Interval (i) }=\frac{R}{K} \quad & \\
& \\
& =\frac{30}{6.28} \\
& =4.7 \\
& =5
\end{array}
\end{aligned}
$$

Based on the frequency distribution above, it had found that the students who got the score $85-89$, they were 3 students or $7.5 \%$, while the students who got the score $80-84$, they were 4 students or $10 \%$, the score $75-79$ were 5 students or $12.5 \%$, the score $70-74$ were 12 students or $30 \%, 65-69$ were 8 students or $20 \%$, the score of $60-64$ were 5 students of $12.5 \%$, and the last score $55-59$, they were 3 or $7.5 \%$.

The calculation of the data of speaking ability taught before using peer tutorial method at the grade VIII SMP Negeri 2 Angkola Timur.

a. Mean in pre-test

$$
\mathrm{M}_{\mathrm{x}}=\frac{\sum X}{N}=\frac{3220}{40}=80.5
$$

b. Standard deviation in pre-test 


$$
\begin{aligned}
& \mathrm{SD}_{\mathrm{X}}=\sqrt{\frac{\sum X_{1}^{2}}{N}} \\
& \mathrm{SD}_{\mathrm{X}}=\sqrt{\frac{2540}{40}} \\
& \mathrm{SD}_{\mathrm{X}}=\sqrt{63.5} \\
& \mathrm{SD}_{\mathrm{X}}=7.96
\end{aligned}
$$

c. Standard error in pre-test

$$
\begin{aligned}
& \mathrm{SE}_{\mathrm{MX}}=\frac{S D_{X}}{\sqrt{N-1}} \\
& \mathrm{SE}_{\mathrm{MX}}=\frac{7.96}{\sqrt{39}} \\
& \mathrm{SE}_{\mathrm{MX}}=\frac{7.96}{6.24} \\
& \mathrm{SE}_{\mathrm{MX}}=1.27
\end{aligned}
$$

2. The calculation of the data of speaking ability in post-test of SMP Negeri 2 Angkola Timur.

a. Mean in post-test

$$
\mathrm{M}_{\mathrm{y}}=\frac{\sum X}{N}=\frac{2775}{40}=69.3
$$

b. Standard deviation of Posttest

$$
\begin{aligned}
& \mathrm{SD}_{Y}=\sqrt{\frac{\sum Y_{1}^{2}}{N}} \\
& \mathrm{SD}_{\mathrm{Y}}=\sqrt{\frac{2559.6}{40}} \\
& \mathrm{SD}_{\mathrm{Y}}=\sqrt{63.9} \\
& \mathrm{SD}_{\mathrm{Y}}=7.9
\end{aligned}
$$

c. Standard Error of post-test

$$
\begin{aligned}
& \mathrm{SE}_{\mathrm{MY}}=\frac{S D_{Y}}{\sqrt{N-1}} \\
& \mathrm{SE}_{\mathrm{MY}}=\frac{7.9}{\sqrt{39}} \\
& \mathrm{SE}_{\mathrm{MY}}=\frac{7.9}{6.24} \\
& \mathrm{SE}_{\mathrm{MY}}=1.26
\end{aligned}
$$

3. The calculation of Standard errors of $\mathrm{X}$ and Yvariables, and calculation to get the score of $t_{0}$ of SMP Negeri 2 Angkola Timur.

a. The calculation of Standard errors of $\mathrm{X}$ and Yvariables by using formula as follows:

$$
\begin{gathered}
\sqrt{\text { SEMX }^{2}+\text { SEMY }^{2}} \\
= \\
\sqrt{1.06^{2}+1.07^{2}} \\
= \\
\sqrt{1.1236+1.1449} \\
=\sqrt{2.2685} \\
=1.51
\end{gathered}
$$$$
\mathrm{SE}_{\mathrm{M} 1}-\mathrm{SE}_{\mathrm{M} 2}=
$$

b. The score of $t_{0}$ by applying the formula as follows :

$$
\begin{aligned}
\mathrm{t}_{\mathrm{o}} & =\frac{M_{X}-M_{Y}}{S E_{M X}-S E_{M Y}} \\
& =\frac{79-73}{1.50} \\
& =\frac{6}{1.51} \\
& =3.97
\end{aligned}
$$


Based on the previous calculation, it has found that the coefficient of $t_{0}=3.97$. It is compared with the score of $t_{t}$ on degree of freedom (df) 78 or $\left(\mathrm{N}_{1}+\right.$ $\left.\mathrm{N}_{2}-2\right)=40+40-2=78$. The score of $t_{t}$ is 1.99 at $5 \%$ significant degree. It means that the score of $t_{0}$ is greater than the score of $t_{t}$ namely $=3.97>1.99$. It meant, there was Significant Effect of Using Peer Tutorial Method in Speaking Ability at SMP Negeri 2 Angkola Timur In other words, the hypothesis is accepted

\section{DISCUSSION}

In doing the research, the researcher had tried to use as much as possible ways in order to make the research better, however, this research is still not perfect in which there are certainly many mistakes and weakness of the research such as lack of knowledge, the way of writing, the instruments of the test which are not good, the calculation, the data analysis, funding and timing. Besides that, the researcher realizes that there are some weaknesses from the student's condition, and concentration in answering the question and the writer hopes the teacher can increase the method in teaching English especially in teaching speaking ability so the students can increase their achievement and increase successful teaching.

\begin{abstract}
In spite of those weaknesses, however, the researcher can make it as the first experience to do further research. Hopefully, this research might be as a reference for other researchers in carrying out other research.
\end{abstract}

\section{CONCLUSION SUGGESTION}

AND

\section{Conclusion}

Based on the result of this research, the conclusion can be formulated as follows:

a. The result of the data description shows that the mean scores of students result in pre-test can be said that the criteria is very good.

b. The result of the data description shows that the mean scores of students result in pre-test can be said that the criteria is enough

c. There is an effect of using peer tutorial in teaching speaking ability of SMP Negeri 2 Angkola Timur.

\section{Suggestions}

Looking to the conclusions above, there were many suggestions which could be applied on this research. The suggestions were created to have connection with students, teacher of English, and other people who interested on this research. To make it clear, the suggestions were showed into following statements.

a. The teacher must give stimulation or support for students who get difficulties to make concluding, to praise 
students who active in peer tutorial method process.

b. Teaching speaking ability by using peer tutorial method will be better if the students effective in getting the trainees to think constructively while increasing with the rest of their learning process.

c. Further, research applies the result of this study as ground to make other research, to improvement of teaching English.

\section{REFERENCES}

Allyn and Bacon, 1999, Active Learning 101 Strategies to Teach Any Subject, Masschussetts : A Simon \& Schuster Company.

Barras, Robert, 2006, Speaking Your Self, A Guide for Students New York: Routledge.

Daradjat Z, et.al., 2008,Metodik Khusus Pengajaran Agama Islam, Jakarta: Bumi Aksara.

Grugeon,Elizabeth, et.al., 2000, Teaching Speaking \& Listening in the Primary School, London: David Fulthon Publisher.

Hedge, Tricia, 2008, Teaching and Learning in the Language Classroom, New York: Oxford University Press.
Louma, Sari,2009, Assesing Speaking, New York: Cumbridge University Press.

McCarten, Jeanne, 2007, Teahing

Vocabulary, Lesson from the

Corpus, Lesson for the

Classroom, New York:

Cambridge University Press.

Nation, I.S.P. , and Jonathan Newton, 2009,Teaching ESL/EFL Listening and Speaking, New York: Routledge.

Permen Diknas RI No 22 Thn 2006, 2006, Tentang Standar Isi, Jakarta : Depdiknas.

Ramayulis, 2001,Metodologi Pengajaran Agama Islam, Jakarta: Kalam Mulia.

Sagala S, 2003, Konsep dan Makna

Pembelajaran, Bandung: Alfabeta.

Taber, Keith, 2007, Class Room-based Research, Evidance-based Practise, A Student's Guide, London: Sage Published.

Vandana, et.al., 2006, Doing Development Research, London: SAGE Publication, Ltd. 